\title{
Development of Mass Production Hatchery Technology for the Redclaw Crayfish, Cherax quadricarinatus
}

\author{
Clive M. Jones ${ }^{1, *}$ and Colin Valverde ${ }^{2}$ \\ ${ }^{1}$ Principal Research Fellow, James Cook University, P.O. Box 6811, Cairns, Queensland, 4870 Australia. \\ ${ }^{*}$ Corresponding Author._clive.jones@jcu.edu.au \\ ${ }^{2}$ AquaVerde, P.O. Box 830, Atherton, Queensland, 4883 Australia. \\ E-mail._info@aquaverde.com.au
}

A B S T R A C T

Aquaculture production of redclaw, Cherax quadricarinatus (von Martens), in Australia has never reached the high level projections made in the 1990's (Jones and Ruscoe 1996). This can be attributed to a range of factors, but the most significant is the supply of seedstock. Although redclaw is advantaged by its uncomplicated reproductive biology with no free-living larval stages, reliance on natural reproduction to generate juveniles for growout purposes is inefficient. An alternative approach involves the artificial incubation of fertilized eggs to improve both quality and quantity of juveniles produced. Suitable technology for such incubation was developed in Europe to support the on-going efforts to produce crayfish plague free juveniles for restocking to natural water bodies. This technology has now been adapted to suit redclaw and for the purpose of mass production of seed crayfish for aquaculture. This paper details the development of the AquaVerde hatchery system, and the challenges to see it develop into fully commercial production, that could support expansion of the redclaw farming industry, both in Australia and elsewhere in the world.

Copyright $(\mathcal{2} 2020$ by The Author(s). Published by the International Association of Astacology. This article is distributed under the terms of the Creative Commons Attribution License (CC-BY 4.0), which permits unrestricted use, distribution, and reproduction in any medium, provided the original author and source are credited.

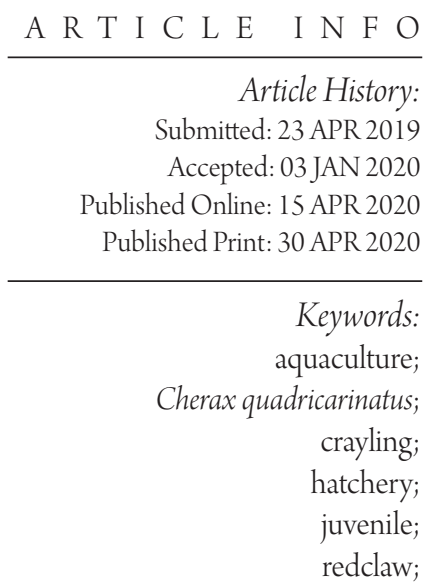

1995 b, 1995c), is relatively easily managed, but generates only modest numbers of juveniles and occupies valuable pond space that might otherwise be used for growout.

\section{RESULTS AND DISCUSSION}

\section{Seed Supply}

Nearly all successful commercial aquaculture operations are characterized by reliable, year-round and cost-effective supplies of seedstock. For redclaw, the on-farm approach, whereby growout farmers produced their own seedstock, was borne out of necessity and maintained by the ease of production. Redclaw have no freeliving larval stages, and there is no requirement for sophisticated, larval rearing hatchery systems to produce seed. On-farm seedstock production can be simply managed by stocking mature male and female crayfish together under summer conditions of day length and temperature. Over a period of three to four months, the broodstock mate, eggs are incubated, and juveniles are generated (Jones 1995a). This has been the standard industry method to generate juveniles for on-growing — managed, on-farm production. However, this approach is somewhat inefficient as the 


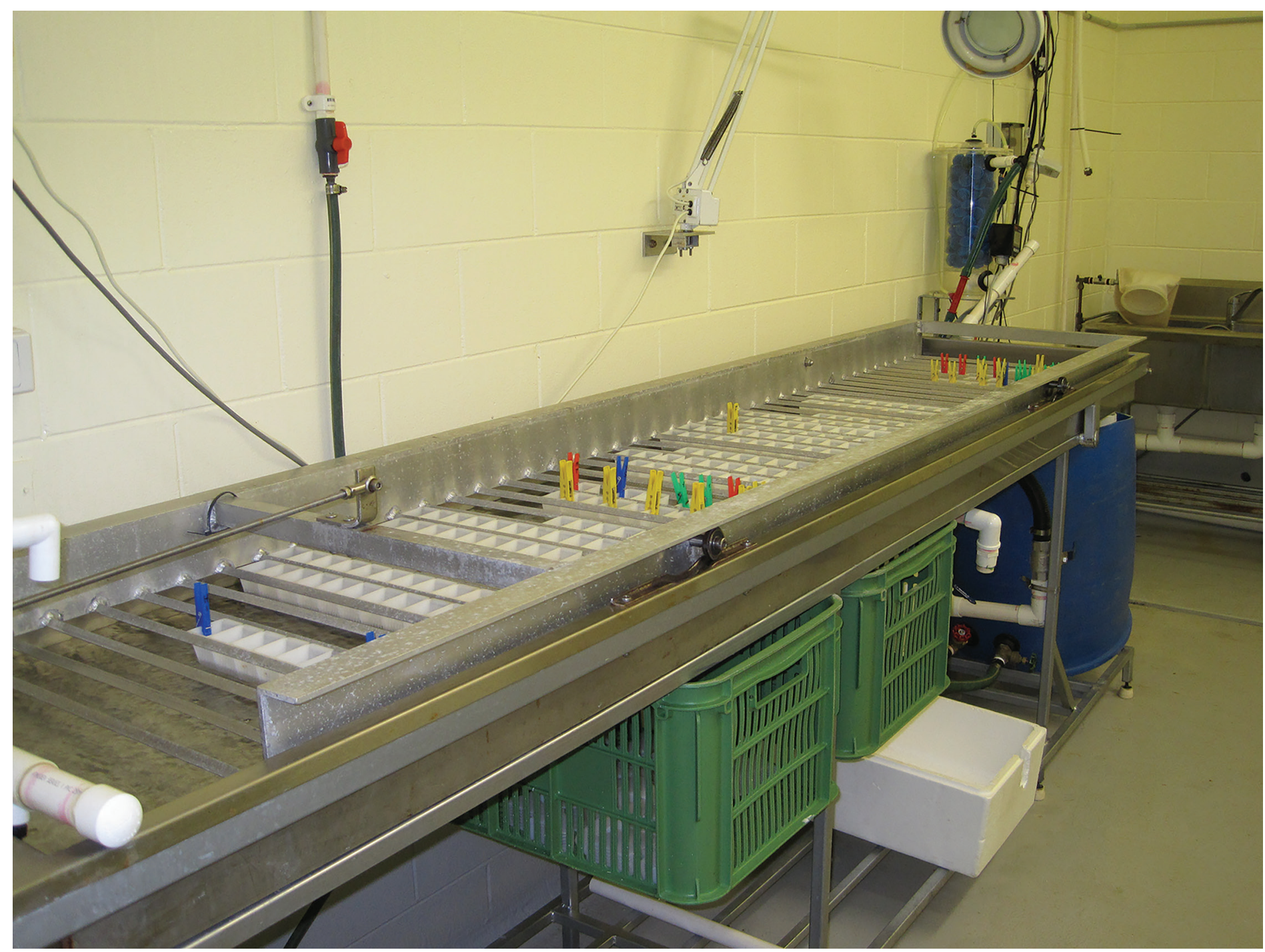

Figure 1. Photo of the AquaVerde incubator, featuring the 3 meter long stainless steel tank, furnished with rows of white plastic baskets containing the crayfish eggs.

number of juveniles produced per female broodstock is relatively low. In a series of pond trials, Jones (1995c) estimated the number of advanced juveniles (approximately $0.5 \mathrm{~g}$ mean weight) produced per broodstock female to be 63.2, with a range of 21.7 to 96.0 . Given the fecundity of redclaw is in the order of 300 to over 1000 per brood (Jones 1990), juvenile production of less than 100 per brood is poor. Using this semi-natural breeding approach to juvenile production involves significant natural mortality and appears to be inefficient.

The standard industry approach for juvenile production involves stocking of 0.1 ha $\left(1000 \mathrm{~m}^{2}\right)$ earthen ponds with broodstock at 250 female to 100 male crayfish. Anecdotal data indicates this type of stocking generates a return of 80 to 100 advanced juveniles per female, equivalent to 20,000 to 25,000 juveniles produced per pond. One such crop requires a 4-month production period to allow for breeding, incubation, and on-growing of craylings to a size suitable for harvest ( 1 to 5 grams each) using a flow trap (a harvesting device that harnesses the redclaw proclivity to walk against a water current - see Curtis (1990)), and of a size suitable for stocking to growout ponds. Such managed pond production of juveniles requires provision of artificial shelters for the juvenile crayfish (typically 1 shelter per $4 \mathrm{~m}^{2}, 250$ shelters per pond), and managed plankton production to provide a source of suitable food for the juvenile crayfish. This can be considered as a semi-intensive approach with relatively high operational costs.

Advanced juveniles generated by pond-based production are typically sorted by size into uniform sized groups and stocked to standard 0.1 ha growout ponds at 5 to 10 crayfish $\mathrm{m}^{-2}$. Consequently, 10,000 juveniles are required per pond. Assuming 3 juvenile crops can be produced each year (i.e., 4 month production time), each juvenile production pond can generate 75,000 advanced juveniles per year, sufficient, at a stocking density of $10 \mathrm{~m}^{-2}$, to stock seven growout ponds. On this basis, approximately $14 \%$ of the ponds on a typical redclaw farm are dedicated to juvenile production, effectively generating no income. This was the primary stimulus for AquaVerde to consider alternatives that might make better use of farm resources and provide more cost-effective production of redclaw seed stock. Central to this consideration was the approach 
of most successful, commercial aquaculture, involving hatcheries that focused exclusively on the production of seed. No larval rearing would be involved, but more intensive management of egg incubation and hatching might facilitate higher survival of offspring and therefore greater numbers of juveniles per broodstock female. The putative advantages of artificial egg incubation include savings of space, water and energy, minimizing egg loss, control over the period of embryogenesis, known parentage for genetic selection and prevention of transmission of disease from parent to offspring. It is worth noting that for traditional, pondbased, juvenile production, the assumption of three crops per year applies only to tropical regions and where suitable temperatures prevail for nine or more months in each year. In areas with more protracted winter conditions and cooler temperatures, it may only be possible to generate two juvenile crops per year.

\section{Hatchery Considerations}

It was in 1997 that the Finnish designed Hemputin apparatus was first considered for application to Australian redclaw for the purpose of generating specific pathogen free offspring to minimize disease issues (Edgerton 1996; Edgerton and Owens 1997). Despite the interest and the apparent suitability of the apparatus, no action was taken at that time. Subsequently in 2005, Colin Valverde, a redclaw farmer in northeastern Australia, purchased a Hemputin system from Finland and transported it to his AquaVerde farm in north Queensland, with the intention of developing a commercial redclaw hatchery. Based upon early success in producing juvenile crayfish, it was also subsequently used as part of a selective breeding program (Stevenson et al. 2013) which had the combined intention of improving stock quality and eliminating disease. During the course of the early experiences including the selective breeding program from 2007 to 2010, adaptations to the original Hemputin were made to better suit the characteristics of redclaw and the requirements for selective breeding.

Artificial incubation of freshwater crayfish eggs has a long history in Europe and elsewhere as a means to accelerate incubation for producing disease-free juveniles for stocking purposes, but not for aquaculture (Mason 1977; Carral et al. 1992; Pérez et al. 1998, 1999; Leonard et al. 2001; Saez-Royuela et al. 2001; GarcíaGuerrero et al. 2003; Henryon and Purvis 2003; Celada et al. 2004; Nakata et al. 2004; Melendre et al. 2006; González et al. 2009; Sáez-Royuela et al. 2009; González et al. 2010; Kouba et al. 2010; Mickeniene and Šyvokiene 2011; Kouba et al. 2012; González et al. 2013). Multiple species and approaches were involved, culminating in the first and possibly only 'commercial' system, named the Hemputin.

The Hemputin was designed for Astacus astacus (Linnaeus) and Pacifastacus leniusculus (Dana) using low water temperature, and accommodating the protracted incubation and small egg numbers of these species. It was developed by Teuvo Järvenpää and others in Finland. Upon using the Hemputin in Australia with redclaw, Colin Valverde found several design features incompatible with the higher temperature requirement, shorter incubation period and higher fecundity of redclaw. Substantial modifications were necessary and the resulting apparatus was assigned its own name, the AquaVerde Incubator, first applied to incubating redclaw eggs in 2008. The AquaVerde incubator, in its original form, consisted of a shallow, rectangular stainless steel tank, 3 meters long, $600 \mathrm{~mm}$ wide and $150 \mathrm{~mm}$ deep (Figure 1). It is supplied with recirculating water applying a proprietary blend of advanced bio-filtration apparatus and water treatment protocols to ensure the highest quality water. An internal stainless steel frame within the tank was fashioned to house proprietary perforated plastic baskets, of approximately $100 \mathrm{ml}$ capacity, each of which holds the eggs from an individual female, typically 300 to 1,000 eggs. The entire frame is harnessed to a motorized agitator to affect a rotary movement that causes the baskets to be gently swayed to and fro within the water, effectively simulating the wafting of the egg-bearing pleopods of the female crayfish. The entire system has capacity for 300 baskets and up to 300,000 eggs, although typically it is stocked with 100,000 to 200,000 eggs.

The hatchery procedure at AquaVerde comprises firstly broodstock (mature male and female crayfish) being stocked to tanks within a breeding facility with both water temperature and photoperiod controlled, to provide summer equivalent conditions, approximately $26^{\circ} \mathrm{C}$ and $14: 10$ light:dark. Optimal nutrition is provided to the broodstock and breeding begins naturally and quickly. Daily examination identifies egg-bearing females that are isolated into separate tanks for the first 2-3 weeks of egg incubation, to reach the eyed stage (Jones 1990). At this stage, the females are taken from the tank and the eggs are carefully removed from the pleopods using forceps to gently but firmly strip the eggs from the ovigerous setae to which they are attached and directly into a beaker of sterilized water. A proprietary disinfectant is applied to the egg bath for several minutes, and then the eggs are poured into the incubation basket within the incubator. Care is taken to examine all of the eggs and remove those that appear to be unviable.

In the AquaVerde hatchery, each female is typically 1 to 2 years old and produces 500 to 1,000 eggs per brood. Of these, typically greater than $90 \%$ hatch successfully within the incubator after 3 to 4 weeks. The aim is to stock the incubator with eggs at the same stage so their development is synchronous and the entire incubator can be harvested at one time. For routine production, the average output is 180,000 craylings per batch, although this is not guaranteed, as significant mortality within a batch occurs from time to time.

For clarity of definition, the term crayling refers to the $3^{\text {rd }}$ instar juvenile after hatch. Within the incubator, the eggs hatch to reveal the first instar. These subsequently moult within the baskets to reach the $2^{\text {nd }}$ instar and are retained within the incubator until the second moult which reveals the $3^{\text {rd }}$ instar, referred to as the crayling. The crayling is the first stage to have the same morphometry as the adult and the term was applied by AquaVerde to provide an unambiguous nomenclature for this transitional stage. The craylings are removed from the incubator and sold for stocking to growout ponds. The subsequent stage after molting again (third post-hatch moult), typically within another 7 days, is referred to as a stage 1 juvenile or J1. Subsequently, stage 2, 3, 4, etc., juveniles follow through to maturity at around 6 to 9 months (Jones 1990). 
Each crayling is typically $16 \mathrm{mg}$ in weight and approximately $10 \mathrm{~mm}$ in total length, and although understandably delicate, are relatively easy to transport. They are typically placed into plastic bags, 2,000 craylings per liter of clean, cool $\left(22\right.$ to $\left.24^{\circ} \mathrm{C}\right)$, wellaerated water. The bags are sealed with rubber bands and placed into a styrofoam box, sometimes with an ice pack, depending on the mode of transport and expected duration. From the AquaVerde farm, transport to the destination of most customers is completed within 24 to 48 hours, either by road or air.

Over the past 10 years of developing the AquaVerde Incubator, there have been many refinements to the apparatus and procedures, and many lessons learnt from the trial and error of stocking the very small craylings that have come from it, as compared with stocking of advanced juveniles produced on-farm, as used in conventional stocking. Results have been variable, with redclaw farmers reporting a wide range of production statistics from very low to very high survival and low to very high growth rates. In one on-farm trial, with hatchery generated craylings stocked to 8 commercial, earthen ponds, survival averaged over $60 \%$ for 7 of the ponds, and in only one pond was survival very low at $7.5 \%$ after 11 weeks of culture (Valverde et al. 2019). This suggests that stocking craylings directly to ponds can be effective. However, over the span of the past decade and hundreds of stockings of AquaVerde produced craylings on multiple farms, production has been inconsistent and survival highly variable.

Such variability is anathema to commercial operations, where consistency is key to planning expected production and sales. This has stimulated the consideration that a nursery phase may be necessary to complement the hatchery production of craylings, with an outcome of producing advanced juveniles whose performance, once stocked to a pond, is more consistent and commercially acceptable. The nature of such a nursery phase, tank or pondbased, its duration and the manner of management, are all subject to on-going research by industry and at James Cook University (Queensland, Australia). Aspects of optimal temperature, crayfish density, provision of habitat and nutrition and feeding husbandry are under investigation. While the results of this research to date have developed some recommended practices, it remains inconclusive that a separate nursery phase is necessary. There is conjecture that improving the quality (robustness) and consistency of hatchery produced craylings during the hatchery rearing, may obviate the need for a nursery.

The hatchery itself is also subject to further refinement of operations, particularly in relation to hygiene. Over the past decade of commercial operations, there has been an unacceptably high incidence of mass mortality of eggs and/or crayfish prior to the crayling stage. Mortality has been primarily attributed to bacterial proliferation, particularly of Aeromonas hydrophila (Chester). Various interventions have been tried to prevent and/or treat such outbreaks including application of ozonation of water supply, inoculation with bacteriophages (Valverde et al. 2019) and other disinfection protocols. Although improvements have been made and egg survival today is significantly higher than it was 10 years ago, there is still some way to go to achieve an acceptable consistency.
Despite the success of the AquaVerde incubator in producing many millions of viable craylings over the past 10 years, there has been no expansion of such hatchery production until recently. A second commercial operator, Australian Crayfish Hatchery (https:// redclawhatchery.com.au), began operating in 2017, initially adopting the AquaVerde incubator approach. Australian Crayfish Hatchery has since made its own modifications to further perfect the incubation technology and to work towards gaining further control over the broodstock management to achieve year-round supply. AquaVerde and Australian Crayfish Hatchery's goal is to achieve a scale of production sufficient to supply the seedstock needs of the entire existing redclaw farming industry and well beyond, to enable significant expansion of redclaw farming.

The Australian redclaw aquaculture industry is ready to embrace the supply of seed from hatchery production, and to devote all of their ponds to growout, divesting themselves of onfarm juvenile production. There is estimated to be existing demand for up to 50 million redclaw seed per year, that if converted to $100 \mathrm{~g}$ redclaw, would represent 4,000 tonnes of annual production. Unrealized forecasts of redclaw aquaculture production have been a feature of the industry's development since the early 1990's. Perhaps with a foundation of hatchery supplied seed, the predicted bright future of redclaw farming, in Australia and elsewhere, will finally be achieved.

\section{LITERATURE CITED}

Carral JM, Celada JD, González J, Gaudioso VR, Fernández R AND LóPEZ-BAIsSón C (1992). Artificial incubation of crayfish eggs (Pacifastacus leniusculus Dana) from early stages of embryonic development. Aquaculture 104(3-4):261269. doi: 10.1016/0044-8486(92)90208-3

Celada JD, Carral JM, Sáez-Royuela M, Melendre PM and Aguilera A (2004). Effects of different antifungal treatments on artificial incubation of the astacid crayfish (Pacifastacus leniusculus Dana) eggs. Aquaculture 239(1-4):249-259. doi: 10.1016/j.aquaculture.2004.06.003

CURTIS M (1990). Flow trapping. Australian Fisheries 49(11):20. In: Australian Fisheries, Aquaculture Special: Redclaw. Macreadie M (ed.). Australian Government Publishing Service, Canberra.

Edgerton B AND Owens L (1997). Age at first infection of Cherax quadricarinatus by Cherax quadricarinatus bacilliform virus and Cherax Giardiavirus-like virus, and production of putative virus-free crayfish. Aquaculture 152(1-4):1-12. doi: 10.1016/ S0044-8486(97)00006-9

EDGERTON BF (1996). Viruses of freshwater crayfish. PhD Thesis. James Cook University, Townsville, Queensland, Australia. Pp. 133.

García-Guerrero M, Villarreal H and Racotta IS (2003). Effect of temperature on lipids, proteins, and carbohydrates levels during development from egg extrusion to juvenile stage of Cherax quadricarinatus (Decapoda: Parastacidae). Comparative Biochemistry and Physiology - A Molecular and Integrative Physiology 135(1):147-154. doi: 10.1016/S10956433(02)00354-9 
González A, Celada JD, González R, García V, Carral JM AND SÁEZ-RoYUELA M (2010). Increasing density in artificial incubation of crayfish eggs (Pacifastacus leniusculus, Astacidae). Freshwater Crayfish 17:19-21.

González A, Celada JD, Melendre PM, Carral JM, SáezRoyuela M, González R and García V (2013). Effects of different bronopol treatments on final survival rates in the artificial incubation of crayfish eggs (Pacifastacus leniusculus, Astacidae). Aquaculture Research 44(3):354-358. doi: 10.1111/j.1365-2109.2011.03036.x

González R, Celada JD, García V, González Á, Carral JM AND SÁEz-Royuela M (2009). The artificial incubation of crayfish eggs: Review and report from an experimental study concerning the effects of offspring origin (maternal or artificial incubation) on the survival and growth of juvenile signal crayfish (Pacifastacus leniusculus, Astacidae). Reviews in Fish Biology and Fisheries 19(2):167-176. doi: 10.1007/ s11160-008-9095-9

Henryon M AND PuRvis IW (2003). Eggs and hatchlings of the freshwater crayfish, marron (Cherax tenuimanus Smith), can be artificially incubated at high population densities, and are most successfully incubated at water temperatures between $20^{\circ} \mathrm{C}$ and $24^{\circ} \mathrm{C}$. Aquaculture Research 34(14):1311-1319. doi: $10.1046 / j .1365-2109.2003 .00942 . x$

Johnston B And Jones CM (2001). Redclaw Profit. Version 1.1. Department of Primary Industries, Brisbane.

Jones CM (1990). The Biology and Aquaculture Potential of the Tropical Freshwater Crayfish, Cherax quadricarinatus. Q190028. Department of Primary Industries, Queensland, Brisbane, Australia.

JoNes CM (1995a). Production of juvenile redclaw crayfish, Cherax quadricarinatus (von Martens)(Decapoda, Parastacidae) I. Development of hatchery and nursery procedures. Aquaculture 138(1995):221-238. doi: 10.1016/0044-8486(95)00068-2

Jones CM (1995b). Production of juvenile redclaw crayfish, Cherax quadricarinatus (von Martens)(Decapoda, Parastacidae) II. Juvenile nutrition and habitat. Aquaculture 138(1995):239245. doi: $10.1016 / 0044-8486(95) 00069-0$

JONES CM (1995c). Production of juvenile redclaw crayfish, Cherax quadricarinatus (von Martens)(Decapoda, Parastacidae) III. Managed pond production trials. Aquaculture 138(1995):247255. doi: $10.1016 / 0044-8486(95) 00067-4$

Kouba A, Carral JM, Buřič M, Mráz J, Policar T and KozÁx P (2010). Artificial incubation of noble crayfish (Astacus astacus) eggs in a partially recirculating system using formaldehyde as an antifungal treatment. Aquaculture Research 41(10):e618e623. doi: 10.1111/j.1365-2109.2010.02569.x

Kouba A, Niksirat H, Kuklina I, BuŘič M and Kozák P (2012). Ultraviolet light and semi-recirculating systems in artificial incubation of noble crayfish (Astacus astacus) eggs: Opportunities and limitations. Aquaculture Research 44(1):67-74. doi: 10.1111/j.1365-2109.2011.03010.x

Leonard BV, Lennard WA and Kildea DG (2001). A method for testing the effectiveness of artificial incubation of eggs vs. maternal brooding in the freshwater crayfish Cherax destructor (Decapoda: Parastacidae). Aquaculture 195(34):299-309. doi: 10.1016/S0044-8486(00)00561-5

MAson JC (1977). Artificial incubation of crayfish eggs (Pacifastacus leniusculus (Dana)). Freshwater Crayfish 3:119-132.

Medley PB, Jones CM And Avault JWJ (1994a). A global perspective of the culture of Australian redclaw crayfish, Cherax quadricarinatus: production, economics and marketing. World Aquaculture 25(4):6-13.

Medley PB, Nelson RG, Hatch LU, Rouse DB and Pinto GF (1994b). Economic feasibility and risk analysis of Australian red claw crayfish Cherax quadricarinatus aquaculture in the southeastern United States. Journal of the World Aquaculture Society 25(1):135-146. doi: 10.1111/j.1749-7345.1994. tb00813.x

Melendre PM, Celada JD, Carral JM, Sáez-Royuela M and Aguilera A (2006). Effectiveness of antifungal treatments during artificial incubation of the signal crayfish eggs (Pacifastacus leniusculus Dana. Astacidae). Aquaculture 257(1-4):257-265. doi: 10.1016/j.aquaculture.2006.02.064

Mickeniene L AND Šyvokiene J (2011). The study of bacteria on artificially incubated noble crayfish eggs. Inland Water Biology 4(2):137-142. doi: 10.1134/S1995082911020271

Nakata K, Matsubara H and Goshima S (2004). Artificial incubation of Japanese crayfish (Cambaroides japonicus) eggs by using a simple, easy method with a microplate. Aquaculture 230(1-4):273-279. doi: 10.1016/j.aquaculture. 2003.08.025

Pérez JR, Carral JM, Celada JD, Muñoz C, Sáez-Royuela M AND ANTOLÍN JI (1998). Effects of stripping time on the success of the artificial incubation of white-clawed crayfish, Austropotamobius pallipes (Lereboullet), eggs. Aquaculture Research 29(6):389-395. doi: 10.1046/j.13652109.1998.00214.x

Pérez JR, Carral JM, Celada JD, Muñoz C, Sáez-Royuela M AND ANTolín JI (1999). The possibilities for artificial incubation of white-clawed crayfish (Austropotamobius pallipes Lereboullet) eggs: Comparison between maternal and artificial incubation. Aquaculture 170(1):29-35. doi: 10.1016/ S0044-8486(98)00389-5

Saez-Royuela M, Celada JD, Muñoz C, Perez JR and CARRAL JM (2001). Effects of different thermal treatments on the maternal incubation efficiency of the astacid crayfish Austropotamobius pallipes (Lereboullet, 1858) under controlled conditions. Crustaceana 74(9):801-808. doi: $10.1163 / 15685400152682575$

Sáez-Royuela M, Melendre PM, Celada JD, Carral JM, González A, GonzÁlez R and García V (2009). Possibilities of artificial incubation of signal crayfish (Pacifastacus leniusculus Dana) eggs at high densities and reduced flow rate using formaldehyde as antifungal treatment. Aquaculture 288(1-2):65-68. doi: 10.1016/j.aquaculture.2008.11.014

Stevenson J, Jerry D and Owens L (2013). Redclaw Selective Breeding Project. RIRDC Publication No. 13/007 RIRDC 
Project No. PRJ-000327 Final Report. Pp. 47. Rural Industries Research and Development Corporation, Canberra.

Valverde C, Jones C, Rigg D, Elliott L, Owens L and Elliman $\mathrm{J}$ (2019). Eliminate factors inhibiting redclaw farming from reaching its full potential. Advances to improving survival of redclaw from hatch to harvest. Final Report for Project No. PRJ-00938. Pp. 120. AgriFutures Australia Final Report. AgriFutures Australia, Canberra. 